\title{
Interactions of fibronectin with Treponema pallidum
}

\author{
T J FITZGERALD* AND L A REPESH† \\ From the Departments of *Medical Microbiology and Immunology, and + Biomedical Anatomy, School \\ of Medicine, University of Minnesota, Duluth, Minnesota, USA
}

SUMMARY The adhesive or opsonic glycoprotein, fibronectin, is associated with the surface of Treponema pallidum as shown by immunofluorescence. A quantitative assay using iodine-125 $\left.{ }^{125} \mathrm{I}\right)$ showed that $T$ pallidum harvested seven days after infection bound more fibronectin than $T$ pallidum harvested 14 days after infection. This increased binding by "younger" organisms was confirmed by radioimmunoassay techniques. Fibronectin appears to have a role in treponemal attachment. Preincubation of $T$ pallidum with goat or rabbit antibody to fibronectin blocked treponemal attachment to cultured cells and to isolated capillaries and inhibited treponemal virulence. Treponemes were incubated in glass wool columns pretreated with fibronectin and were then eluted from the columns. This technique yielded a population of $T$ pallidum that failed to bind to fibronectin. Compared with treponemes eluted from control ovalbumin columns, organisms eluted from fibronectin columns attached to cultured cells in larger numbers but did not survive as long and were not as virulent. Findings are discussed in terms of the relevence of interaction between treponemes and fibronectin in the pathogenesis of $T$ pallidum.

\section{Introduction}

Fibronectin is an adhesive or opsonic glycoprotein that contains specific binding sites for a wide variety of substrates including collagen, fibrinogen or fibrin, actin, glycosaminoglycans, proteoglycans, DNA, plasma transglutaminase, cultured cells, and bacteria. ${ }^{1-5}$ This glycoprotein occurs in both soluble and insoluble forms. Large amounts $(300 \mathrm{mg} / \mathrm{l})$ of soluble fibronectin are present in the blood, and smaller amounts in the cerebrospinal fluid, amniotic fluid, and saliva. Soluble fibronectin enhances macrophage phagocytosis, ${ }^{6-10}$ and may act as a nonspecific opsonin in helping to clear particulate matter from the blood. Insoluble fibronectin is a major component of basement membranes and extracellular matrices. It appears to play a part in the adhesion of cells to substrata and in cell spreading and cell morphology. ${ }^{1-5}$

In 1978, using heat killed formalin fixed Staphylococcus aureus, Kuusela first showed that fibronectin attaches to bacteria. ${ }^{11}$ Subsequent reports have shown that fibronectin binds to many Gram positive bacteria including groups $A, C$, and $G$ streptococci, ${ }^{12-14}$ other species of staphylococci, ${ }^{15}$

\footnotetext{
Address for reprints: Dr T J Fitzgerald, Department of Medical Microbiology and Immunology, School of Medicine, University of Minnesota at Duluth, Duluth, Minnesota 55812, USA

Accepted for publication 16 October 1984
}

and oral streptococci. ${ }^{16}$ Gram negative organisms such as Escherichia coli, ${ }^{16}$ Pseudomonas aeruginosa, ${ }^{17}$ and Klebsiella pneumoniae, ${ }^{17}$ also bind very small amounts of fibronectin. In two other reports, fibronectin was shown to attach to Candida albicans $^{18}$ and to viral envelope glycoproteins isolated from influenza $A$, parainfluenza 1 , and mumps viruses. ${ }^{19}$ These studies have pointed to the potential role of fibronectin in mediating the attachment of micro-organisms to host tissues.

The attachment of pathogenic treponemes to cultured cells and non-attachment of non-pathogenic treponemes has suggested that attachment is an important part of treponemal pathogenesis. ${ }^{20-22} \mathrm{We}$ first reported that antibodies to fibronectin blocked treponemal attachment to cultured cells and suggested that fibronectin might be involved in treponemal attachment (Fitzgerald TJ and Repesh LA, unpublished observation, UCLA Symposium on the Molecular Biology of Host-parasite Interactions, 1983). Peterson et al extended this preliminary observation. ${ }^{23}$ They found that antibodies to fibronectin blocked the attachment of treponemes to Hep 2 cells and that fibronectin reacted with three treponemal surface proteins previously implicated by Baseman and Hayes in the attachment process. ${ }^{24}$

We set out to investigate the relevance of interactions between treponemes and fibronectin in the pathogenesis of $T$ pallidum. Within hours of entering the host, organisms "metastasise" via the blood- 
stream and lymphatic system. ${ }^{25}$ As with disseminating tumour cells, this invasive process may be important in infecting most tissues in the secondary stage of syphilis. The mechanisms of the migration of treponemes through the interstitial matrices containing collagen I and fibronectin are poorly understood. One possibility is that there are at least two different populations of $T$ pallidum. Organisms that bind fibronectin may remain localised within the extracellular matrix at the site of entry and induce the primary lesion. Organisms that do not bind fibronectin may make their way through the extracellular matrix that is rich in fibronectin, penetrate vascular channels, disseminate to other tissues, and induce secondary lesions. ${ }^{26}$

\section{Materials and methods}

\section{TREPONEMES}

The Nichols strain of $T$ pallidum was injected intratesticularly into rabbits using $20 \times 10^{6}$ to $40 \times 10^{6}$ organisms per testis. Rabbits were given daily intramuscular injections of cortisone acetate $(6 \mathrm{mg} / \mathrm{kg}$ body weight). After seven to 14 days of infection, treponemes were extracted in medium containing $\mathbf{9 0 \%}$ McCoy's medium, $10 \%$ heat inactivated rabbit serum, $1 \mathrm{mmol} / 1$ dithiothreitol, and $30 \mathrm{mmol} / 1$ $\mathrm{N}$-2-hydroxyethylpiperazine- $\mathrm{N}^{1}$-2-ethanesulphonic acid (HEPES) pH 7.2 with a rotary shaker at room temperature for 25 minutes. ${ }^{25}$ The suspension was centrifuged at $1000 \times g$ for 10 minutes at room temperature to sediment gross particulates. The supernatant fraction containing the organisms was then centrifuged at $12000 \times g$ for 30 minutes at $4^{\circ} \mathrm{C}$. The pelleted treponemes were resuspended in either phosphate buffered saline (PBS) $\mathrm{pH} \mathrm{7.0}$ or in extraction medium. Experiments in which viable organisms were incubated for various times were undertaken in an atmosphere of $2.5 \%$ oxygen, $5 \%$ carbon dioxide, and $92.5 \%$ nitrogen (which is hereafter referred to as $2.5 \%$ oxygen). In some experiments, organisms were trypsinised to remove fibronectin already bound to the surface. Treponemes were resuspended in trypsin $(0 \cdot 25 \%)$ and edetic acid (EDTA) $(0.01 \%)$ for 10 minutes, centrifuged, washed in 10 volumes of PBS, and resuspended in PBS at a concentration of $50 \times$ $10^{6} / \mathrm{ml}$.

\section{BINDING RADIOIODINATED FIBRONECTIN} Commercially prepared iodine-125 $\left({ }^{225} \mathrm{I}\right)$ fibronectin was obtained from New England Nuclear (Boston, Massachusetts, USA). A volume of $50 \mu$ l treponemes in PBS at a concentration of $200 \times 10^{6} / \mathrm{ml}$ was added to flat bottomed wells in microtitre plates (Linbro, McLean, Virginia, USA), air dryed at room temperature, and fixed by adding $60 \mu \mathrm{l} 10 \%$ ethanol and air drying. ${ }^{28} 29 \mathrm{~A}$ volume of $50 \mu{ }^{125} \mathrm{I}$ fibronectin (equivalent to 100000 counts per minute (cpm)) was added to each well and incubated for various times at $37^{\circ} \mathrm{C}$. Unbound label was removed by washing with $2.5 \mathrm{ml}$ PBS, and wells were cut out and assessed for ${ }^{125}$ I activity using a Beckman $\mathbf{4 0 0 0}$ gamma counter. Each experiment was performed in triplicate four to six times.

IMMUNOLOGICAL DETECTION OF FIBRONECTIN Fibronectin associated with the treponemal surface was also shown by radioimmunoassay in microtitre plates containing 96 round bottomed wells (Linbro). We used procedures identical, with one modification, to those previously described for $T$ pallidum. ${ }^{28} 29$ Briefly, $10 \mu \mathrm{l}$ of treponemes in PBS at a concentration of $50 \times 10^{6} / \mathrm{ml}$ were air dried in wells, fixed with $20 \mu \mathrm{l} \mathrm{10 \%}$ ethanol, and air dried. At this point, previous procedures used $100 \mu \mathrm{l} 2 \%$ ovalbumin to minimise non-specific binding. We omitted this step as it effectively covered the fibronectin on $T$ pallidum, making it non-reactive. A volume of $100 \mu \mathrm{l}$ rabbit anti-human fibronectin (Cappel, Malvern, Pensylvania, USA, and Bethesda Research Laboratories, Maryland, USA) diluted by $1 / 100$ was added to the test wells; the corresponding control wells received normal rabbit serum diluted by $1 / 100$. After being left for one hour at $37^{\circ} \mathrm{C}$, wells were washed to remove unbound antibody, and a volume of $100 \mu \mathrm{l}$ ${ }^{125}$ I protein A (New England Nuclear) equivalent to $100000 \mathrm{cpm}$ was added and left for a further hour at $37^{\circ} \mathrm{C}$. The wells were then washed, cut out, and assessed for radioactivity. Each experiment was performed in quadruplicate on five occasions. Preliminary experiments using human fibronectin as the antigen and various dilutions of goat or rabbit antiserum indicated optimum reactivity of both antisera at a dilution of $1 / 100$. The rabbit antiserum consistently contained more antibodies to fibronectin than the goat antiserum. In further experiments to assess the sensitivity of this assay, human fibronectin at decreasing concentrations was added as antigen, followed by a $1 / 100$ dilution of antiserum to fibronectin. The minimum amount of fibronectin detectable using either goat or rabbit antiserum to fibronectin was $3 \mathrm{ng}$ per well, which corresponded to about $200 \mathrm{cpm}$.

A second method involving immunofluorescence was used to confirm the presence of fibronectin on the surface of treponemes. ${ }^{30}$ Treponemes were incubated for 24 hours with cultured rabbit testicular cells growing on glass coverslips. ${ }^{31}$ Unattached organisms were removed by washing with 10 volumes of extraction medium. The coverslips were fixed in $10 \%$ methanol for 20 seconds. Rabbit antiserum to 
fibronectin or the control of normal rabbit serum diluted by 1/500 were added and incubated for an hour at $37^{\circ} \mathrm{C}$. The preparations were washed by dipping three times in PBS and incubated with goat anti-rabbit IgG labelled with fluorescein isothiocyanate (FITC) (Miles Laboratories, Naperville, Illinois, USA) diluted $1 / 400$ for an hour at $37^{\circ} \mathrm{C}$. The coverslips were washed in PBS, a drop of $10 \%$ buffered glycerol was added, and fluorescence was observed. Maximum reactivity was recorded as $4+$ and minimum reactivity as $1+$. Chequerboard titrations of both the antiserum to fibronectin and the anti-IgG were performed to assess the optimum dilutions of antisera. These experiments were performed on three occasions.

\section{BLOCKAGE OF ATTACHMENT}

Treponemes suspended in extraction medium at 20 $\times 10^{6} / \mathrm{ml}$ were preincubated for 18 hours in $2.5 \%$ oxygen with goat or rabbit antiserum to fibronectin, or with normal goat or normal rabbit serum as controls. Various dilutions of antiserum were tested for blockage, and 1/50 was optimum. The treponemes were then added to the following substrates: human fibronectin at $100 \mathrm{mg} / \mathrm{l}$ dried on glass coverslips, ${ }^{25}$ different types of cultured cells, ${ }^{20}$ or intact capillaries isolated from rabbit brains. ${ }^{32}$ After incubation for two to four hours at $37^{\circ} \mathrm{C}$ in $2 \cdot 5 \%$ oxygen, the numbers of treponemes that were attached were compared as described previously. ${ }^{21}$ Experiments using each substrate were performed in duplicate on five occasions.

\section{VIRULENCE}

Protocols similar to those listed for attachment were used. Treponemes $\left(0.1 \times 10^{6} / \mathrm{ml}\right)$ were incubated for 18 or 42 hours at $37^{\circ} \mathrm{C}$ in $2.5 \%$ oxygen with goat or rabbit antiserum or, as controls, normal goat or normal rabbit serum. A volume of $0.1 \mathrm{ml}$ was injected intradermally into the shaved backs of Dutch Belt rabbits. A total of 24 rabbits were injected with duplicate samples. The incubation periods refer to the time between injection and initial clinical appearance of erythema and induration. Samples taken from representative lesions were observed for actively motile treponemes by dark field microscopy.

\section{GLASS WOOL EXPERIMENTS}

To deplete the treponemes that attached to fibronectin, $2 \mathrm{ml}$ sterile glass wool was packed into a $3 \mathrm{ml}$ syringe. The wool columns were washed with $50 \mathrm{ml}$ PBS, and $2 \mathrm{ml}$ human fibronectin at $100 \mathrm{mg} / \mathrm{l}$ (or $2 \mathrm{ml} 2 \%$ ovalbumin as the control) were added to the columns and incubated for an hour at room temperature. Both columns were washed with $50 \mathrm{ml}$ PBS to remove unbound fibronectin or ovalbumin. A volume of $2 \mathrm{ml}$ of treponemes was then added to each column, and incubated for 0 to 120 minutes at $37^{\circ} \mathrm{C}$ in $2.5 \%$ oxygen. Treponemes were then eluted from the columns and counted. These experiments were repeated on three occasions.

\section{SOURCES OF FIBRONECTIN}

Affinity purified human fibronectin was obtained from Bethesda Research Laboratories or from Sigma Chemicals (St Louis, Missouri, USA). Affinity purified rabbit fibronectin was kindly provided by $\mathrm{Dr}$ Brett Steiner, University of Texas, Houston, USA. Stock solutions were prepared and stored at $-20^{\circ} \mathrm{C}$ in glass tubes coated with $2 \%$ ovalbumin for 30 minutes. This coating prevented non-specific binding of the fibronectin to the storage vessel. To coat glass coverslips, $100 \mathrm{mg} / \mathrm{l}$ fibronectin was air dried in a volume of $0.3 \mathrm{ml}$ of solution. ${ }^{25}$

\section{Results}

\section{IMMUNOFLUORESCENCE}

We used immunofluorescence techniques and antibody to fibronectin to localise fibronectin. Cultured cells were incubated with $T$ pallidum and then washed to remove unattached organisms. The cultured cells that contained fibronectin provided the positive control. As with the observations of other workers, ${ }^{1-5}$ the fibronectin on the cultured cells was distributed over the entire surface, with heavier accumulations at the edges of cells, especially at points of contact with other cells. Attached treponemes also fluoresced, which indicated fibronectin associated with the treponemal surfaces. Fluorescence was evenly distributed over the entire length of the organisms and was not localised only at the ends.

\section{RADIOIMMUNOASSAY}

In preliminary experiments, varying amounts of fibronectin were associated with the surface of treponemes using organisms harvested at different days after inoculation. To assess whether this reflected the stage of infection, organisms were harvested seven and 14 days after infection and resuspended in PBS. Portions of both treponemal preparations were trypsinised to remove endogenous fibronectin. Treponemes and trypsinised treponemes were fixed in flat bottomed microtitre wells and incubated with ${ }^{125}$ I fibronectin for $0,10,20,30,40$, 50 , and 60 minutes. After being washed to remove unbound label, wells were cut out, and residual radioactivity was measured (figure). Treponemes harvested earlier (at day 7) bound more fibronectin that those harvested later (at day 14). In addition, 


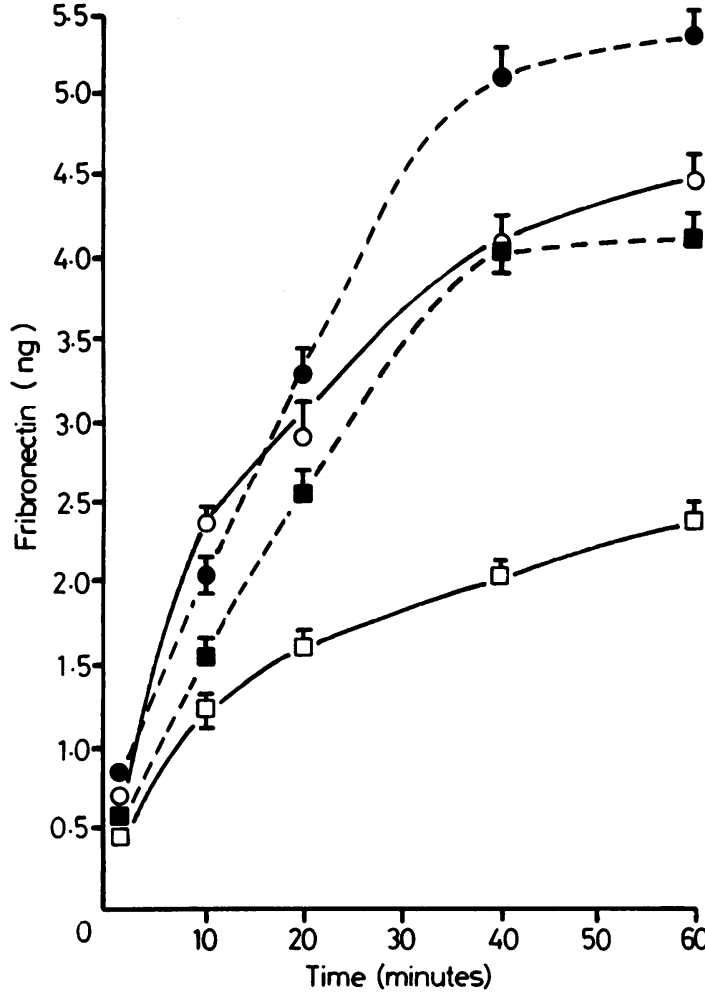

FIGURE Residual radioactivity (expressed as $\mathrm{ng}$ fibronectin) at various times after adding iodine-125 to trypsinised and non-trypsinised Treponema pallidum organisms harvested at day 7 and day 14 after infection. $\mathrm{C}=$ day 7 trypsinised treponemes, $\mathrm{O}=$ day 7 treponemes, $\square=$ day 14 trypsinised treponemes; $\square=$ day 14 treponemes) Experiments were performed in triplicate 4-6 times; bars represent SEM.

prior trypsinisation of organisms resulted in increased amounts of bound label. Thus less exogenous fibronectin bound to the surface of the organisms as infection progressed.
TABLE I Results of four radioimmunoassays showing antigenic reactivity to fibronectin of treponemes harvested seven days after infection

\begin{tabular}{llll}
\hline & \multicolumn{3}{l}{ Reactivity (counts per minute) of: } \\
\cline { 2 - 4 } Experiment & $\begin{array}{l}\text { Normal } \\
\text { rabbit serum }\end{array}$ & $\begin{array}{l}\text { Rabbit } \\
\text { antiserum }\end{array}$ & Difference \\
\hline 1 & 12403 & 12703 & 300 \\
2 & 15844 & 20174 & 4330 \\
3 & 15285 & 17203 & 1918 \\
4 & 9648 & 13183 & 3535 \\
Mean (SEM)* & $13295(715)$ & $15816(884)$ & 2521 \\
\hline *Standard error of the mean for five separate experiments using \\
triplicate samples.
\end{tabular}

Radioimmunoassay procedures were used as another way of measuring differential binding of fibronectin by treponemes. $T$ pallidum was harvested from animals seven and 14 days after infection, fixed in wells, and exposed to normal serum versus antiserum to fibronectin. As table I shows, endogenous fibronectin was detected on the organisms harvested on day 7. The organisms harvested on day 14, however, failed to react with the antiserum to fibronectin, which indicated differential binding of fibronectin.

\section{BLOCKAGE OF ATTACHMENT}

In preliminary experiments antiserum to fibronectin partly blocked treponemal attachment to cultured cells. Additional experiments were performed with goat or rabbit antiserum to fibronectin using cultured rabbit testis cells, cultured rabbit dermis cells, Hep 2 cells, and isolated rabbit capillaries. Treponemes were preincubated for $\mathbf{1 8}$ hours with normal goat or normal rabbit serum or goat or rabbit antiserum to fibronectin. The treated organisms were then added to the three types of cultured cells, the capillaries, or glass coverslips coated with fibronectin. After being incubated for two to four hours, the attached treponemes were counted (table II). The specificity

TABLE II Blockage of attachment of Treponema pallidum to different preparations after preincubation for 2-4 hours with goat or rabbit antiserum to fibronectin

\begin{tabular}{|c|c|c|c|c|c|}
\hline \multirow[b]{2}{*}{ Substrate } & \multicolumn{3}{|c|}{$\begin{array}{l}\text { Mean (SEM) No of treponemes attached after } \\
\text { incubation with: }\end{array}$} & \multicolumn{2}{|c|}{ \% inhibition by: } \\
\hline & $\begin{array}{l}\text { Normal goat or } \\
\text { rabbit serum }\end{array}$ & $\begin{array}{l}\text { Goat } \\
\text { antiserum }\end{array}$ & $\begin{array}{l}\text { Rabbit } \\
\text { antiserum }\end{array}$ & $\begin{array}{l}\text { Goat } \\
\text { antiserum }\end{array}$ & $\begin{array}{l}\text { Rabbit } \\
\text { antiserum }\end{array}$ \\
\hline \multirow{5}{*}{$\begin{array}{l}\text { Coverslips coated with fibronectin } \\
\text { (treponemes/400 } \times \text { magnification) } \\
\text { Cultured rabbit testis cells } \\
\text { (treponemes/cultured cell) } \\
\text { Cultured rabbit dermis cells } \\
\text { (treponemes/cultured cell) } \\
\text { Cultured human Hep-2 cells } \\
\text { (treponemes/cultured cell) } \\
\text { Isolated rabbit capillaries } \\
\text { (treponemes/capillary) }\end{array}$} & $25 \cdot 0(5 \cdot 2)^{*}$ & $4 \cdot 9(2 \cdot 2)$ & $5 \cdot 2(1 \cdot 8)$ & 80 & 79 \\
\hline & $19 \cdot 0(1 \cdot 9)$ & $12 \cdot 5(1 \cdot 4)$ & $11 \cdot 2(3 \cdot 3)$ & 34 & 41 \\
\hline & $23 \cdot 5(1 \cdot 0)$ & $17 \cdot 0(1 \cdot 2)$ & $14 \cdot 5(2 \cdot 4)$ & 28 & 38 \\
\hline & $11 \cdot 2(0 \cdot 7)$ & $7 \cdot 4(1 \cdot 0)$ & $6 \cdot 4(1 \cdot 3)$ & 34 & 43 \\
\hline & $16 \cdot 5(1 \cdot 0)$ & $11 \cdot 6(3 \cdot 1)$ & $10 \cdot 0(3 \cdot 4)$ & 30 & 39 \\
\hline
\end{tabular}

* Standard error of the mean of five experiments per preparation. 
of the goat and rabbit antiserum to fibronectin was indicated by the $80 \%$ and $79 \%$ blockage of attachment to the coverslips coated with fibronectin. Blockage of attachment by both antisera also occurred with each cell type and with the capillaries. The degree of blockage was consistent and ranged between $28 \%$ and $41 \%$. We were unable to increase the degree of blockage by using longer preincubation of organisms, increased concentrations of antiserum, or decreased concentrations of $T$ pallidum.

\section{VIRULENCE}

We performed related experiments to assess whether the antiserum to fibronectin would decrease treponemal virulence. $T$ pallidum was incubated with normal goat or normal rabbit serum or goat or rabbit antiserum to fibronectin for 18 or 42 hours; 24 rabbits were then inoculated intradermally (table III). Virulence of $T$ pallidum was not affected by the antiserum during the first $\mathbf{1 8}$ hours, when the incubation periods (days to the appearance of erythema and induration) and the total sites developing lesions were similar to those of the controls. Incubation for $\mathbf{4 2}$ hours resulted in decreased treponemal virulence. The incubation period was extended 2.9 days with goat antiserum and 7.5 days with rabbit antiserum; in addition, fewer sites developed lesions with the two anti sera. Antiserum to fibronectin therefore decreased treponemal virulence.

\section{CROSS REACTIVITY}

It was surprising that rabbit antiserum to fibronectin reacted with the fibronectin associated with treponemes that was probably of rabbit origin. We therefore used radioimmunoassay procedures to investigate whether rabbit antiserum reacted with rabbit fibronectin. $T$ pallidum was trypsinised to remove endogenous fibronectin and then incubated for one hour with $100 \mathrm{mg} / \mathrm{l}$ affinity purified human fibronectin or affinity purified rabbit fibronectin. Unbound fibronectin was removed by centrifuging and washing the treponemes. The following five antigenic preparations were air dried and fixed in microtitre wells: human fibronectin, rabbit fibro-
TABLE III Virulence of treponemes after preincubation with goat or rabbit antiserum to fibronectin

\begin{tabular}{|c|c|c|}
\hline Preparation & $\begin{array}{l}\text { Mean }(S E M)^{*} \text { days } \\
\text { to appearance of } \\
\text { erythema and } \\
\text { induration }\end{array}$ & $\begin{array}{l}\text { No (\%) sites } \\
\text { developing } \\
\text { lesions/sites } \\
\text { inoculated }\end{array}$ \\
\hline $\begin{array}{l}\text { Normal goat/rabbit serum } \\
\text { Goat antiserum } \\
\text { Rabbit antiserum }\end{array}$ & $\begin{array}{l}18 \cdot 8(1 \cdot 4) \\
21 \cdot 7(1 \cdot 5) \\
26 \cdot 3(1 \cdot 7)\end{array}$ & $\begin{array}{l}23 / 24(96) \\
19 / 24(79) \\
18 / 24(75)\end{array}$ \\
\hline
\end{tabular}

*Standard error of the mean for 24 sites inoculated.

nectin, treponemes, treponemes previously incubated with human fibronectin, and treponemes previously incubated with rabbit fibronectin. Each set of wells was then tested with normal rabbit serum (negative control), immune rabbit serum (positive control), or rabbit antiserum to fibronectin (table IV). Compared with normal rabbit serum, immune rabbit serum gave low levels of activity in wells containing human fibronectin ( $762 \mathrm{cpm}$ more) or rabbit fibronectin $(545 \mathrm{cpm}$ more), which indicated that immune rabbit serum contained antibodies to fibronectin. In the wells containing the three treponemal antigenic preparations, exposure to immune rabbit serum yielded higher levels of activity $(>5300 \mathrm{cpm}$ more than normal rabbit serum). This was expected as immune rabbit serum was the positive control. It also showed that the bound fibronectin did not interfere with recognition of antibody. Interesting results were obtained compared with normal rabbit serum when the five antigenic preparations were incubated with rabbit antiserum to fibronectin. This antiserum reacted strongly with human fibronectin $(8711 \mathrm{cpm}$ more), which was expected as rabbit antiserum to fibronectin should readily cross react with human fibronectin. The rabbit antiserum to fibronectin also reacted weakly with rabbit fibronectin $(511 \mathrm{cpm}$ more than with normal rabbit serum). Similarly the treponemes previously incubated with human fibronectin reacted strongly, and those previously incubated with rabbit fibronectin reacted weakly. These results show that rabbit antiserum to fibronectin reacts with rabbit fibronectin.

TABLE IV Results of radioimmunoassays showing reactivity of rabbit antiserum to fibronectin with rabbit fibronectin

\begin{tabular}{|c|c|c|c|c|c|}
\hline \multirow[b]{2}{*}{ Antigenic preparation coating plastic wells } & \multicolumn{5}{|c|}{ Mean (SEM)* counts per minute of: } \\
\hline & $\begin{array}{l}\text { Normal rabbit } \\
\text { serum }\end{array}$ & $\begin{array}{l}\text { Immune rabbit } \\
\text { serum }\end{array}$ & $\begin{array}{l}\text { Net } \\
\text { difference }\end{array}$ & $\begin{array}{l}\text { Rabbit } \\
\text { antiserum }\end{array}$ & $\begin{array}{l}\text { Net } \\
\text { difference }\end{array}$ \\
\hline $\begin{array}{l}\text { Human fibronectin } \\
\text { Rabbit fibronectin } \\
\text { Treponemes } \\
\text { Treponemes previously incubated with }\end{array}$ & $\begin{array}{l}1324(264) \\
1947(404) \\
2066(295)\end{array}$ & $\begin{array}{l}2086(495) \\
2492(508) \\
7403(1205)\end{array}$ & $\begin{array}{r}762 \\
545 \\
5337\end{array}$ & $\begin{array}{r}10035(1690) \\
2458(493) \\
2377(432)\end{array}$ & $\begin{array}{r}8711 \\
511 \\
311\end{array}$ \\
\hline $\begin{array}{l}\text { human fibronectin } \\
\text { Treponemes previously incubated with }\end{array}$ & $2270(324)$ & $7661(1206)$ & 5391 & 8075 (1466) & 5805 \\
\hline rabbit fibronectin & $1803(338)$ & 7496 (1235) & 5693 & $2334(451)$ & 531 \\
\hline
\end{tabular}

*Standard error of the mean of three separate experiments using triplicate samples. 
TABLE V Attachment of treponemes to glass wool treated with fibronectin or ovalbumin

\begin{tabular}{|c|c|c|c|c|}
\hline \multirow[b]{2}{*}{ Time (min) } & \multicolumn{2}{|c|}{ Ovalbumin glass wool } & \multicolumn{2}{|c|}{ Fibronectin glass wool } \\
\hline & $\begin{array}{l}\text { Mean }(S E M)^{*} \\
\text { treponemes } \\
\text { eluted } \\
\left(\times 10^{7} / \mathrm{ml}\right)\end{array}$ & $\%$ decrease & $\begin{array}{l}\text { Mean }(S E M)^{*} \\
\text { treponemes } \\
\text { eluted } \\
\left(\times 10^{7} / \mathrm{ml}\right)\end{array}$ & $\%$ decrease \\
\hline $\begin{array}{r}0 \\
30 \\
60 \\
120\end{array}$ & $\begin{array}{l}3 \cdot 17(0.6) \\
3 \cdot 17(0.2) \\
2 \cdot 83(0.2) \\
2 \cdot 92(0.6)\end{array}$ & $\begin{array}{r}0 \\
0 \\
11 \\
8\end{array}$ & $\begin{array}{l}3 \cdot 17(0.6) \\
2 \cdot 17(0.7) \\
2 \cdot 08(0.5) \\
1.58(0.2)\end{array}$ & $\begin{array}{r}0 \\
32 \\
34 \\
50\end{array}$ \\
\hline
\end{tabular}

*Standard error of the mean of three separate experiments using duplicate samples.

\section{GLASS WOOL EXPERIMENTS}

The data in table II indicate that goat or rabbit antiserum partly, but not totally, blocked treponemal attachment to cultured cells (28\% to $41 \%$ blockage). The inability to attain better blockage may reflect different populations of $T$ pallidum, some of which do not bind to cultured cells through fibronectin and are therefore not affected by antiserum to fibronectin. To show different populations, treponemes from day 7 infections were incubated in glass wool columns precoated with fibronectin or (as a control) ovalbumin. After incubation for 0 to 120 minutes, samples were eluted from each column and treponemes were counted (table V). After the first 30 minutes, $32 \%$ of the organisms were retained in the fibronectin column compared with none in the ovalbumin column. After 120 minutes, $50 \%$ of the organisms were retained in the fibronectin column compared with $8 \%$ in the ovalbumin column. When these experiments were repeated using $T$ pallidum from day 14 infections, few treponemes were retained in the fibronectin column. This agrees with the observations in table I, the figure, and table II, in which the day 14 treponemes bound fibronectin or reacted poorly with antiserum to fibronectin.

The glass wool technique at least partly depleted the population of treponemes that bind fibronectin. In the last series of experiments, attempts were made to identify differences in this population. Organisms were added to columns treated with ovalbumin or fibronectin. After 30 minutes treponemes were eluted from both columns and adjusted to equal concentrations. Both preparations were then added to coverslips coated with fibronectin (to indicate specificity of depletion) or to cultured cells (to assess treponemal attachment and survival), or were immediately inoculated intradermally into rabbits (to assess virulence). Table VI shows the differences between the two preparations of $T$ pallidum. Using organisms eluted from the fibronectin column, $70 \%$ fewer treponemes were attached to coverslips coated with fibronectin, which indicated partial depletion of the organisms binding to fibronectin; whereas larger numbers attached to the cultured cells but did not survive as long. In addition, this population of $T$ pallidum exhibited longer incubation periods in vivo, which indicated differences in virulence. These three variables show differences in the two populations of treponemes.

\section{Discussion}

Our earlier studies pointed to reactivity of fibronectin with $T$ pallidum. Organisms adhered to glass coverslips coated with fibronectin, and IgG from serum immune to syphilis blocked that attachment. ${ }^{25}$ In addition, attachment of treponemes to cultured cells was partly blocked by pretreatment of organisms with antibodies to fibronectin (Fitzgerald TJ, Repesh LA, unpublished observation, UCLA Symposium on the Molecular Biology of Hostparasite Interactions, 1983). The findings reported

TABLE VI Attachment, survival, and virulence of treponemes eluted from glass wool treated with ovalbumin or fibronectin

\begin{tabular}{|c|c|c|}
\hline & $\begin{array}{l}\text { Ovalbumin } \\
\text { glass wool }\end{array}$ & $\begin{array}{l}\text { fibronectin } \\
\text { glass wool }\end{array}$ \\
\hline $\begin{array}{l}\text { Treponemes incubated for } 10 \text { hours on coverslips coated with fibronectin: } \\
\text { Mean (SEM)* organisms } / 400 \times \text { magnification } \\
\text { Treponemes incubated for six hours with cultured cells: }\end{array}$ & $70 \cdot 7(2 \cdot 5)$ & $21 \cdot 2(2 \cdot 1)$ \\
\hline $\begin{array}{l}\text { Treponemes incubated for six hours with cultured cells: } \\
\text { Mean (SEM)* attached/cell } \\
\text { Mean (SEM)* hours to } 50 \% \text { motility }\end{array}$ & $\begin{array}{l}21 \cdot 3(3 \cdot 5) \\
68 \cdot 2(16 \cdot 3)\end{array}$ & $\begin{array}{l}36 \cdot 3(4 \cdot 3) \\
29 \cdot 6(3 \cdot 8)\end{array}$ \\
\hline $\begin{array}{l}\text { Treponemes immediately injected intradermally into rabbits: } \\
\text { Mean (SEM)* days to appearance of erythema and induration } \\
\text { No of sites developing lesions/sites inoculated }\end{array}$ & $\begin{array}{l}8 \cdot 8(0 \cdot 9) \\
30 / 32\end{array}$ & $\begin{array}{l}12 \cdot 6(1 \cdot 1) \\
31 / 32\end{array}$ \\
\hline
\end{tabular}

*Standard error of the mean of four experiments using duplicate samples. 
here confirm and extend these earlier studies. The interaction of $T$ pallidum with fibronectin was shown by binding assays using soluble ${ }^{125}$ I human fibronectin. Prior trypsinisation of organisms resulted in increased binding of fibronectin either by removing endogenous fibronectin (which was sensitive to trypsin) or by exposing additional receptors or ligands of fibronectin on the surface of treponemes. The presence of fibronectin on the surface of $T$ pallidum was also shown immunologically by immunofluorescence and radioimmunoassay and by blocked attachment and decreased virulence after preincubation with antiserum to fibronectin.

The binding of fibronectin to $T$ pallidum appears to be different from the binding of fibronectin to cultured cells or other constituents. In unpublished observations treponemes were incubated with ${ }^{125}$ I fibronectin and then centrifuged at high speed to pellet the organisms. This washing procedure removed most of the bound ${ }^{125} \mathrm{I}$ activity. If fibronectin possessed a specific binding site for $T$ pallidum, high speed centrifuging should not disrupt the complex of treponemes and fibronectin. Fibronectin does have a binding site for glycosaminoglycans. $T$ pallidum contains glycosaminoglycans associated with its surface, which are effectively removed by high speed centrifuging. ${ }^{33}$ Fibronectin may bind to these treponemal glycosaminoglycans, which, with their bound fibronectin, would be stripped away by high speed centrifuging. This would explain the relatively weak binding of fibronectin to $T$ pallidum.

Fibronectin binds to other micro-organisms and has been implicated in attachment to different tissues. Myhre and Kuusela ${ }^{13}$ and Switkalski et al ${ }^{12}$ showed that groups A, C, and G streptococci bound fibronectin. Further work presented evidence of two separate binding sites for staphylococci and streptococci. ${ }^{34}$ Simpson and Beachey suggested that fibronectin mediated attachment of group A streptococci to oral epithelial cells through streptococcal lipoteichoic acid. ${ }^{14}$ Espersen and Clemmensen identified a staphylococcal surface protein that bound fibronectin. ${ }^{15}$ Babu et al suggested that cariogenic streptococci attached to dental tissues through the fibronectin present in the pellicle of teeth. ${ }^{16}$ Abraham et al found two different populations of human buccal epithelial cells, one that was heavily coated with fibronectin and one that was not; Streptococcus pyogenes attached only to the buccal cells that contained fibronectin. ${ }^{35}$ In other studies fibronectin has been shown to bind to Salmonella typhimurium, Bacillus subtilis, Saccharamyces cerevisiae, Candida albicans, and viral glycoproteins. ${ }^{19}{ }^{36}$ Fibronectin was first thought to react with Gram positive but not Gram negative bacteria. ${ }^{35}$ Recent studies, however, have indicated that Gram negative bacteria also bind fibronectin, but bind far less than Gram positive bacteria. The quantity of fibronectin bound by $T$ pallidum was quite similar to that reported for Escherichia coli ( $20 \mathrm{ng} / 10^{9}$ cells), Pseudomonas aeruginosa (10 $\mathrm{ng} / 10^{9}$ cells), and Klebsiella pneumoniae ( $7 \mathrm{ng} / 10^{9}$ cells).

Baseman and Hayes identified three putative treponemal proteins that mediate attachment of $T$ pallidum to Hep 2 cells, ${ }^{24}$ and fibronectin has recently been reported to attach to each of these proteins. ${ }^{23}$ Preincubation of Hep 2 cells with antiserum to fibronectin has been shown to result in $84 \%$ blockage of treponemal attachment, which led to the conclusion that attachment of $T$ pallidum to host tissues resulted solely from interactions with fibronectin. We disagree with this explanation for two reasons. Firstly, it is unlikely in view of the clinical manifestations of syphilis. When $T$ pallidum first enters the host, some of the organisms remain localised in the extracellular matrix, multiply, and induce the primary lesion, whereas other organisms disseminate to other tissues within hours via the bloodstream and lymphatic system. If all the treponemes bound fibronectin, they would be unable to penetrate through the extracellular matrix, which is rich in fibronectin, to reach the vascular channels and disseminate. In addition, findings in this report and that of Peterson et al showed that $T$ pallidum binds soluble fibronectin..$^{23}$ Once organisms enter the circulation, therefore, the large excess $(300 \mathrm{mg} / \mathrm{l})$ of soluble fibronectin in the blood would rapidly saturate the fibronectin ligands of the treponemes. If fibronectin ligands are solely responsible for tissue attachment, the organisms with saturated ligands would not be able to attach to other host tissues at sites distant from the primary lesions and induce secondary lesions. Secondly, preincubation of $T$ pallidum with antiserum to fibronectin resulted in partial but not total blockage of attachment $(28 \%$ to $41 \%$ blockage). Various different experimental conditions were tested, but we were unsuccessful in increasing the degree of blockage. Thus some of the organisms apparently attach to cultured cells through mechanisms other than fibronectin. We recently published findings on the ability of $T$ pallidum to attach to laminin, collagens, and glycosaminoglycans, ${ }^{25}$ each of which may be present in different types of cultured cells. Treponemal attachment to these cellular components would not be affected by antibody to fibronectin.

The mechanisms of treponemal attachment to cultured cells are probably quite complex. $T$ pallidum apparently possesses receptors or ligands for fibronectin that could bind direct to the insoluble fibronectin on the surfaces of cultured cells. $T$ pallidum 
also binds soluble fibronectin that is present in both inflamed tissues ${ }^{37}$ and the bloodstream. Fibronectin has binding sites for a wide variety of tissue components (collagens, laminin, and hyaluronic acid) in addition to a binding site for itself. The soluble fibronectin already associated with the treponemal surface could therefore, in turn, bind to the collagen, laminin, hyaluronic acid, and insoluble fibronectin within tissues. Lastly, $T$ pallidum coats itself with hyaluronic acid as infection progresses ${ }^{33}$; treponemal associated hyaluronic acid could bind to the insoluble tissue fibronectin.

The data in Table VI suggest that there are different populations of $T$ pallidum, some of which do not bind fibronectin. For this reason, preincubation with antiserum to fibronectin would not be expected to totally block treponemal attachment to cultured cells. The glass wool experiments indicated that organisms that did not bind fibronectin showed differences in attachment, survival, and virulence. In addition, day 7 treponemes bound more fibronectin and reacted far better with antiserum to fibronectin than day 14 treponemes.

As a biological precedent for different populations of $T$ pallidum, strains within species have been shown to bind varying amounts of fibronectin. Switalski et al showed that 13 of 17 strains of Streptococcus hominis, 11 of 20 strains of Staphylococcus saprophyticus, and four of seven strains of Staphylococcus epidermidis bound fibronectin. ${ }^{12}$ Simpson et al reported variation within seven strains of Streptococcus pyogenes with a range of $63 \mathrm{ng}$ to $1089 \mathrm{ng}$ fibronectin $/ 10^{\circ}$ bacteria. ${ }^{17}$ Espersen and Clemmensen observed variation in binding of fibronectin by different isolates of Staphylococcus aureus. ${ }^{15}$ Myhre and Kuusela found wide variations in fibronectin binding using 387 strains belonging to 35 different species of microorganisms. ${ }^{13}$ Thus it seems likely that $T$ pallidum may vary in its ability to bind fibronectin. Experiments are currently in progress to test the hypothesis that treponemes that fail to bind fibronectin are responsible for disseminated syphilitic infection.

Finally, we were surprised to observe the reactivity of rabbit antiserum to fibronectin with fibronectin associated with treponemes. As there are no reports of biosynthesis of fibronectin by micro-organisms, it is reasonable to assume that the fibronectin on the surface of $T$ pallidum is of rabbit origin. In general, antiserum to fibronectin does not react with fibronectin isolated from the same species. We initially intended to show that goat antiserum to fibronectin would block treponemal attachment, as a positive control, and rabbit antiserum would not, as a negative control. Our data indicated, however, that rabbit antiserum reacted with treponemes in radio- immunoassay, blocked treponemal attachment to cultured cells, and reduced treponemal virulence. The observations in table IV showed that rabbit antiserum to fibronectin did recognise isolated rabbit fibronectin or rabbit fibronectin associated with $T$ pallidum. This confirmed the reports of MurphyUllrich et al, who showed that denaturation of mouse fibronectin resulted in reactivity with mouse antiserum to fibronectin. ${ }^{38}$ The binding of rabbit fibronectin to the surface of treponemes may sufficiently alter the conformation of rabbit fibronectin to render it immunogenic in the rabbit system. This would explain the presence of antibodies to fibronectin in serum immune to syphilis (table IV). We have also detected antibodies to laminin in serum from animals with syphilis (unpublished findings). As a biological precedent, antibodies to laminin develop in Chagas disease. ${ }^{3940}$ It was suggested that Trypanasoma cruzi incorporated the patient's laminin on to its surface, which modified its structure to render it immunogenic. These antibodies, in turn, may contribute to tissue histopathology through an autoimmune like reaction. Similarly, Murphy-Ullrich et al reported autoimmune mediated injury to the glomerular basement membranes in mice immunised with denatured mouse fibronectin or laminin, and in rabbits immunised with human fibronectin. ${ }^{38} 4142$ In syphilis, it has been proposed that autoimmune like phenomena contribute to histopathology of lesions; this is especially well documented in the nephrotic syndrome in secondary syphilis. The antibodies to fibronectin and laminin could partly explain host mediated damage within lesions of syphilis.

We thank Eileen Gannon, Anne Utyro, Brad Ingersoll, and Barb Elmquist for their expert technical help. Without their careful patience in performing the experiments, this research would not have been possible. This work was supported by grants AI 16585 and AI 18619 from the Public Health Service, National Institute of Allergy and Infectious Diseases. We also thank Drs Terry Oberley at the University of Wisconsin, James N Miller at UCLA, Fred Grinnell at the University of Texas, and Hynda Kleinman at NIH for their critical evaluation of this manuscript.

\section{References}

1. Hynes RO. Fibronectin and its relation to cellular structure and behavior. In: Hay ED, ed. Cell biology of the extracellular matrix. New York: Plenum Press, 1981:295-394.

2. Ruoslahti E, Engvall E, Hayman EG. Fibronectin: current concepts of its structure and function. Coll Relat Res 1981;1: 95-110.

3. Yamada KM. Fibronectins-adhesive glycoproteins of cell surface and blood. Nature 1978;275: 179-84.

4. Furcht $L$. Structure and function of the adhesive glycoprotein fibronectin. Mol Cell Biol 1983; 1:53-117.

5. Mosher DF, Furcht LT. Fibronectin: review of its structure and possible functions. $J$ Invest Dermatol 1981;77: 175-80. 
6. Blumenstock FA, Saba TM, Weber $P$. An affinity method for the rapid purification of opsonic alpha 2-SB glycoprotein from serum. In: Schumer W, Spitzger JJ, Marshall BE, eds. Advances in shock research. Vol 2. New York: Alan R Liss, 1979:55-71.

7. Blumenstock FA, Saba TM, Roccario E, Cho E, Kaplan JE Opsonic fibronectin after trauma and particle injection determined by a peritoneal macrophage assay. Research Journal of the Reticuloendothelium Society 1981;30:61-71.

8. Gudewicz PW, Molnar J, Lai MZ, et al. Tibronectin-mediated uptake of gelatin-coated latex particles by peritoneal macrophages. J Cell Biol 1980;87:427-33.

9. Saba TM, Blumenstock FA, Weber P, Kaplan JE. Physiologic role for cold-insoluble globulin in systemic host defense. Implications of its characterization as the opsonic alpha-2-SB glycoprotein. Ann NY Acad Sci 1978; 321:43-55.

10. Saba TM, Jaffe E. Plasma fibronectin (opsonic glycoprotein): its synthesis by vascular endothelial cells and role in cardiopulmonary integrity after trauma as related to reticuloendothelial function. Am J Med 1980;68:577-94.

11. Kuusela P. Fibronectin binds to Staphylococcus aureus. Nature 1978; 276:718-20.

12. Switalkski LM, Ljungh A, Ryden C, Rubin K, Hook M, Wadstron $T$. Binding of fibronectin to the surface of groups $A$, C, and G streptococci. Eur J Clin Microbiol 1982;1:381-7.

13. Myhre EB, Kuusela P. Binding of human fibronectin to groups $A, C$, and $G$ streptococci. Infect Immun 1983;40:29-34.

14. Simpson WA, Beachey EH. Adherence of group A streptococci to fibronectin and oral epithelial cells. Infect Immun 1983;39:275-9.

15. Espersen F, Clemmensen I. Clumping of Staphylococcus aureus by human fibronectin. Acta Pathol Microbiol Scand 1981;89:317-21.

16. Babu JP, Simpson, WA, Courtney HS, Beachey EH. Interaction of human plasma fibronectin with cariogenic and noncariogenic oral streptococci. Infect Immun 1983;41:162-8.

17. Simpson WA, Haty DL, Mason JM, Beachey EH. Fibronectinmediated binding of group A streptococci to human polymorphonuclear leukocytes. Infect Immun 1982;37:805-10.

18. Segal E, Kerk KS, Calderone R, Scheld WM. Clinical Research 1982; 30:378A.

19. Julkunen I, Hautanen A, Keski-Oja J. Interaction of viral envelope glycoproteins with fibronectin. Infect Immun 1983; 40:876-81

20. Fitzgerald TJ, Miller JN, Sykes JA. Treponema pallidum (Nichols strain) in tissue cultures: cellular attachment, entry, and survival. Infect Immun 1975; 11: 1133-40.

21. Fitzgerald TJ, Johnson RC, Miller JN, Sykes JA. Characterization of the attachment of Treponema pallidum (Nichols strain) to cultured mammalian cells and the potentia relationship of attachment to pathogenicity. Infect Immun 1977; 18:467-78.

22. Fieldsteel AH, Stout JG, Becker FA. Comparative behavior of virulent strains of Treponema pallidum and Treponema pertenue in gradient cultures of various mammalian cells. Infect Immun 1979; 24:337-45.

23. Peterson KM, Baseman JB, Alderete JF. Treponema pallidum receptor binding proteins interact with fibronectin. J Exp Med 1983; 157: 1958-70.

24. Baseman JB, Hayes EC. Molecular characterization of receptor binding proteins and immunogens of virulent Treponema pallidum. J Exp Med 1980; 151:573-86.
25. Fitzgerald TJ, Repesh LA, Blanco DR, Miller JN. Attachment of Treponema pallidum to fibronectin, laminin, collagen IV and collagen I and blockage of attachment by immune rabbit IgG. British Journal of Venereal Diseases 1984;60:357-63.

26. Turner TB, Hollander DH. Biology of the treponematoses. WHO Monograph Series 1957; 35: 1-277.

27. Fitzgerald TJ, Repesh LA. J Cell Biochem 1984; 8B:297.

28. Zelzter PM, Pepose JS, Bishop NH, Miller JN. Microassay for immunoglobulin $\mathbf{G}$ antibodies to Treponema pallidum with radioiodinated protein A from Staphylococcus aureus: immunoglobulin $\mathbf{G}$ response in experimental syphilis in rabbits. Infect Immun 1978; 21:163-70.

29. Pepose JS, Bishop NH, Feigenbaum S, Miller JN, Zeltzer PM. The humoral immune response of rabbits infected with Treponema pallidum: comparison of antibody levels measured by the staphylcoccal protein A-IgG (SPA-TP) microassay with VDRL, FTA-ABS, and TPI responses during the development of acquired resistance to challenge. Sex Transm Dis 1980;7: $125-9$.

30. US Public Health Service. Manual of tests for Syphilis. Washington DC: US Dept of Health, Education and Welfare, US Government Printing Office, 1969 (PHS Publication No 411): 1-77.

31. Sykes JA, Moore EB. A simple tissue culture chamber. Tex Rep Biol Med 1960; 18:288-97.

32. Quist EE, Repesh LA, Zeleznikar R, Fitzgerald TJ. Interaction of Treponema pallidum with isolated rabbit capillary tissues. British Journal of Venereal Diseases 1983;59:11-20.

33. Fitzgerald TJ, Miller JN, Repesh LA, Rice M, Urquhart A. Binding of glycosaminoglycans to Treponema pallidum surface and subsequent effects on complement interactions between antigen and antibody. Genitourin Med 1985;61:13-20.

34. Kuusela P, Vartio T, Vuento M, Myhre EB. Binding sites for streptococci and staphylococci in fibronectin. Infect Immun $1984 ; 45: 433-6$

35. Abraham SN, Beachey EH, Simpson WA. Adherence of Streptococcus pyogenes, Escherichia coli, and Pseudomonas aeruginosa to fibronectin-coated and uncoated epithelial cells. Infect Immun 1983; 41:1261-8.

36. Van de Water L, Destree AT, Hynes RO. Fibronectin binds to some bacteria but does not promote their uptake by phagocytic cells. Nature 1983;220:201-4.

37. Richards PS, Saba TM. Fibronectin levels during intraperitoneal inflammation. Infect Immun 1983;39:1411-8.

38. Murphy-Ullich JE, Oberley TD, Mosher DF, Autoimmunemediated injury produced in mice by immunization with homologous fibronectin: effect of denaturation of the immunogen on subsequent localization of tissue injury. $A m \mathrm{~J}$ Pathol (in press).

39. Szarfman A, Terranova BP, Rennard SI, et al. Antibodies to laminin in Chagas disease. $J$ Exp Med 1982; 155:1161-71.

40. Avila JL, Rojas M, Rieher M. Antibodies to laminin in American cutaneous leishmaniasis. Infect Immun 1984;43: 402-6.

41. Murphy-Ullrich JE, Oberley TD. Immune-mediated injury to basement membranes in mice immunized with murine laminin. Clin Immunol Immunopathol 1984;31:33-43.

42. Murphy-Ullrich JE, Oberley TD, Mosher DF. Detection of autoantibodies and glomerular injury in rabbits immunized with denatured human fibronectin monomer. Am J Pathol 1984; 117:1-11. 